\title{
MEASURES FOR ENSURING THE SAFETY AND SECURITY OF AUTOMATED OPERATION OF PUBLIC TRANSPORTATION IN JAPAN
}

\author{
TAKESHI MIZUMA \\ Department of Advanced Energy, University of Tokyo, Japan
}

\begin{abstract}
The technology of automated driving has been making rapid strides in the automobile sector and is quickly moving toward becoming a reality. However, automated driving technology was first implemented in the railway field in the 1970s (mainly as a new type of transportation system), and its safety requirements were stipulated through the International Electrotechnical Commission. In this paper, we describe the safety procedures of automated driving that have been adopted in Japan's public transportation system (railway sector) and explain the techniques for ensuring the security of this technology in the railways of the future and in the incorporation of advanced automated driving technology in the automotive field.

Keywords: automated train operation, safety, security, autonomous driving, RAMS.
\end{abstract}

\section{INTRODUCTION}

Automated driving is used to describe the system known as Automated Urban Guided Transport by the International Electro Committee (IEC), and is applied to vehicles that selfpropel along an assigned track. The automated operation of trains in Japan has a long history. It began in 1976 with automated forwarding in the car shed of the Tozai Line in Sapporo, with full-fledged operation beginning in 1981, with the Port Liner in Kobe and the New Tram in Osaka. Initially, automated driving using rubber tires on elevated tracks became popular as a new transportation system; in 2005, however, the automated operation of subway trains according to international standards was introduced in the Nanakuma line in Fukuoka. Studies are now being made to examine whether an automated operation is possible in older lines.

This paper first defines the automated driving of trains and describes its safety requirements. We then go on to discuss the relationship with the automated driving technology used in automobiles, and the issues involved in applying this technology to railways, and finally reflect on the future course of the automated driving of trains.

This paper is the first application of safety analysis on driverless train operation to subways in Japan. Through our hazard and risk analysis, driverless train operation has realized practical use in Japan.

\section{HISTORY OF AUTOMATED DRIVING IN JAPAN}

Table 1 shows the history of automated driving in Japan. The term "automated driving" used in this paper focuses on driving using automated train operation (ATO). The widespread use of automated operations through ATO, principally in subway trains, has been well established. In the table, STO refers to semi-automated train operation, DTO is driverless train operation, and UTO is unattended train operation, as stipulated in IEC 62267 (international standard for safety requirements of automatic operation). Under the international standard, DTO and UTO are regarded as automated operations. 
Table 1: Present status of (unmanned) automated driving in Japan.

\begin{tabular}{|c|c|c|c|c|c|}
\hline $\begin{array}{c}\text { Implementation } \\
\text { year }\end{array}$ & $\begin{array}{l}\text { Railway } \\
\text { authority }\end{array}$ & Type & Route & $\begin{array}{l}\text { Grade of } \\
\text { automation }\end{array}$ & Remarks \\
\hline 1976 & Sapporo city & Subway & Tozai line & UTO & $\begin{array}{l}\text { Rubber tires, } \\
\text { only in depot }\end{array}$ \\
\hline 1977 & Kobe city & Subway & Seishin & STO & $\begin{array}{l}\text { Conventional } \\
\text { railway }\end{array}$ \\
\hline \multirow[t]{3}{*}{1981} & Kobe city & NTS & Port liner & UTO & $\begin{array}{l}\text { With platform } \\
\text { screen doors }\end{array}$ \\
\hline & Osaka city & NTS & New Tram & UTO & $\begin{array}{l}\text { With platform } \\
\text { screen doors }\end{array}$ \\
\hline & Fukuoka city & Subway & Airport & STO & $\begin{array}{l}\text { With half height } \\
\text { platform }\end{array}$ \\
\hline 1985 & $\begin{array}{l}\text { Kitakyushu } \\
\text { city }\end{array}$ & Monorail & Kokura & STO & $\begin{array}{l}\text { Now change to } \\
\text { manual (NTO) }\end{array}$ \\
\hline 1987 & Sendai city & Subway & Nanboku & STO & $\begin{array}{l}\text { Conventional } \\
\text { railway }\end{array}$ \\
\hline 1988 & Kobe city & Subway & Hokushinkyuko & STO & $\begin{array}{l}\text { Through to } \\
\text { Seishin line }\end{array}$ \\
\hline \multirow[t]{2}{*}{1989} & Nagoya city & Subway & Sakuratorie & STO & $\begin{array}{l}\text { Conventional } \\
\text { railway }\end{array}$ \\
\hline & Yokahama city & NTS & $\begin{array}{c}\text { Kanazawa } \\
\text { hakkei }\end{array}$ & UTO & $\begin{array}{l}\text { With platform } \\
\text { screen doors }\end{array}$ \\
\hline \multirow[t]{2}{*}{1990} & Kobe city & NTS & Rokko island & UTO & $\begin{array}{l}\text { With platform } \\
\text { screen doors }\end{array}$ \\
\hline & Osaka city & Subway & Tsurumiryokuchi & STO & $\begin{array}{c}\text { Linear motor } \\
\text { subway }\end{array}$ \\
\hline \multirow[t]{2}{*}{1991} & $\begin{array}{c}\text { Tokyo } \\
\text { metropolitan }\end{array}$ & Subway & Oedo & STO & $\begin{array}{l}\text { Linear motor } \\
\text { subway }\end{array}$ \\
\hline & Tokyo metro & Subway & Nanboku & STO & $\begin{array}{l}\text { With platform } \\
\text { screen doors }\end{array}$ \\
\hline 1995 & $\begin{array}{c}\text { Tokyo } \\
\text { metropolitan }\end{array}$ & NTS & Yurikamome & UTO & $\begin{array}{l}\text { With platform } \\
\text { screen doors }\end{array}$ \\
\hline 1997 & Kyoto city & Subway & Tozai & STO & $\begin{array}{l}\text { With platform } \\
\text { screen doors }\end{array}$ \\
\hline 1998 & $\begin{array}{c}\text { Tokyo } \\
\text { metropolitan }\end{array}$ & Monorail & Tama & STO & $\begin{array}{c}\text { With half height } \\
\text { platform }\end{array}$ \\
\hline 2000 & $\begin{array}{c}\text { Tokyo } \\
\text { metropolitan }\end{array}$ & Subway & Mita & STO & $\begin{array}{l}\text { With half height } \\
\text { platform }\end{array}$ \\
\hline \multirow[t]{3}{*}{2001} & Saitama & Subway & Saitama kosoku & STO & $\begin{array}{l}\text { Through to } \\
\text { Nanboku line }\end{array}$ \\
\hline & Kobe city & Subway & Kaigan & STO & $\begin{array}{c}\text { Linear motor } \\
\text { subway }\end{array}$ \\
\hline & Disney & Monorail & Maihama & DTO & $\begin{array}{l}\text { With half height } \\
\text { platform }\end{array}$ \\
\hline \multirow[t]{2}{*}{2005} & Fukuoka city & Subway & Nanakuma & DTO & $\begin{array}{c}\text { First DTO } \\
\text { subway in Japan }\end{array}$ \\
\hline & $\begin{array}{c}\text { Aichi } \\
\text { prefecture }\end{array}$ & Maglev & Linimo & DTO/UTO & $\begin{array}{c}\text { DTO in } \\
\text { tunnel/UTO } \\
\text { outside }\end{array}$ \\
\hline 2006 & Osaka city & Subway & Imazatosuji & STO & $\begin{array}{c}\text { Linear motor } \\
\text { subway }\end{array}$ \\
\hline
\end{tabular}


Table 1: Continued.

\begin{tabular}{|c|c|c|c|c|c|}
\hline $\begin{array}{c}\text { Implementation } \\
\text { year }\end{array}$ & $\begin{array}{c}\text { Railway } \\
\text { authority }\end{array}$ & Type & Route & $\begin{array}{c}\text { Grade of } \\
\text { automation }\end{array}$ & Remarks \\
\hline 2007 & Yokohama city & Subway & Blue line & STO & $\begin{array}{c}\text { With half height } \\
\text { platform }\end{array}$ \\
\hline 2008 & Yokohama city & Subway & Green line & STO & $\begin{array}{c}\text { Linear motor } \\
\text { subway }\end{array}$ \\
\hline & Tokyo metro & Subway & Fukutoshin & STO & $\begin{array}{c}\text { With half height } \\
\text { platform }\end{array}$ \\
\hline 2010 & Tokyo metro & Subway & Marunouchi & STO & $\begin{array}{c}\text { With half height } \\
\text { platform }\end{array}$ \\
\hline 2012 & Sapporo city & Subway & Nanboku & STO & $\begin{array}{c}\text { With platform } \\
\text { screen doors }\end{array}$ \\
\hline 2014 & Tokyo metro & Subway & Chiyoda & STO & $\begin{array}{c}\text { With half half height } \\
\text { platform }\end{array}$ \\
\hline 2015 & Osaka city & Subway & Sennichimae & STO & $\begin{array}{c}\text { With half height } \\
\text { platform }\end{array}$ \\
\hline & Nagoya city & Subway & Higashiyama & STO & $\begin{array}{c}\text { With half height } \\
\text { platform }\end{array}$ \\
\hline 2016 & Sendai city & Subway & Tozai & STO & $\begin{array}{c}\text { Linear motor } \\
\text { subway }\end{array}$ \\
\hline & Sapporo city & Subway & Toho & STO & $\begin{array}{c}\text { Rubber tires and } \\
\text { platform fence }\end{array}$ \\
\hline
\end{tabular}

Table 2 shows the operation modes specified by IEC 62267 and their roles. The basic functions of a train operation are defined, and those functions that are carried out by the driver are marked with an $\mathrm{x}$, whereas the functions performed by the system are denoted with an S. The difference between STO and DTO is that, although the driving and maintenance of the security of an operation are carried out by the system in both cases, track monitoring is conducted by the system with DTO, and by the driver with STO. With UTO, the operation of running a train and the security function of detecting and managing abnormalities are also performed by the system, in addition to the functions of the system used with DTO.

Automated driving has been progressively introduced into Japanese trains, mainly in subway trains running on assigned tracks without railroad crossings and in the New Transport System. However, in subway trains, it was developed as an STO, in which the driver also monitors the track for evacuation guidance inside the tunnel. In the New Transport System, it progressed more as UTO because the system can easily monitor the tracks, which are elevated, and evacuation guidance is relatively easy, particularly owing to the use of a guide-rail system.

However, with the call for labor saving techniques and advancements in sensor technologies, automated track-monitoring and responses to emergency situations have become possible to a certain extent, resulting in a move toward the use of DTO in subway trains, as was implemented in the Nanakuma Line of the Fukuoka City Transportation Bureau. For this reason, the design of the trains is such that the system can respond to emergency situations by means of a derailment detection device mounted on the train or using 
Table 2: The operation modes specified by IEC 62267 and their roles.

\begin{tabular}{|c|c|c|c|c|c|c|}
\hline \multirow{2}{*}{\multicolumn{2}{|c|}{ Basic functions of train operation }} & \multirow{2}{*}{ 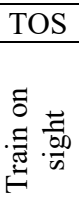 } & NTO & STO & DTO & UTO \\
\hline & & & 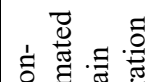 & 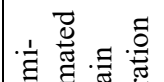 & 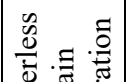 & 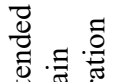 \\
\hline \multirow{3}{*}{$\begin{array}{l}\text { Assurance of } \\
\text { safe driving }\end{array}$} & Assurance of safe route & $x$ & $\mathrm{~S}$ & $\mathrm{~S}$ & $\mathrm{~S}$ & $\mathrm{~S}$ \\
\hline & Assurance of safe distance & $x$ & $\mathrm{~S}$ & $\mathrm{~S}$ & $\mathrm{~S}$ & $\mathrm{~S}$ \\
\hline & Assurance of safe speed & $x$ & $\times / \mathrm{S}$ & $\mathrm{S}$ & $\mathrm{S}$ & $\mathrm{S}$ \\
\hline Driving & $\begin{array}{l}\text { Control of } \\
\text { acceleration/deceleration }\end{array}$ & $x$ & $x$ & $\mathrm{~S}$ & $\mathrm{~S}$ & $\mathrm{~S}$ \\
\hline \multirow{2}{*}{$\begin{array}{l}\text { Supervising the } \\
\text { track }\end{array}$} & $\begin{array}{l}\text { Protection of collisions with } \\
\text { obstacles }\end{array}$ & $x$ & $x$ & $x$ & $\mathrm{~S}$ & $\mathrm{~S}$ \\
\hline & $\begin{array}{l}\text { Protection of collisions with } \\
\text { persons }\end{array}$ & $x$ & $x$ & $x$ & $\mathrm{~S}$ & $\mathrm{~S}$ \\
\hline \multirow{4}{*}{$\begin{array}{l}\text { Supervising of } \\
\text { passengers' } \\
\text { movement }\end{array}$} & Control of vehicle doors & $x$ & $x$ & $x$ & $x$ & $\mathrm{~S}$ \\
\hline & Protection of passengers' & $x$ & $x$ & $x$ & $x$ & $\mathrm{~S}$ \\
\hline & $\begin{array}{l}\text { movement between } \\
\text { platform and vehicle }\end{array}$ & $x$ & $x$ & $x$ & $x$ & $\mathrm{~S}$ \\
\hline & Confirmation of safe start & $x$ & $x$ & $x$ & $x$ & $\mathrm{~S}$ \\
\hline \multirow[t]{2}{*}{ Train operation } & $\begin{array}{l}\text { Set and cancel of train } \\
\text { operation }\end{array}$ & $x$ & $x$ & $x$ & $x$ & $\mathrm{~S}$ \\
\hline & $\begin{array}{l}\text { Supervising the train } \\
\text { situation }\end{array}$ & $x$ & $x$ & $x$ & $x$ & $\mathrm{~S}$ \\
\hline $\begin{array}{l}\text { Confirmation } \\
\text { of detection } \\
\text { and } \\
\text { management in } \\
\text { emergency }\end{array}$ & $\begin{array}{l}\text { Train diagnoses, fire and } \\
\text { smoke detection, derailment } \\
\text { detection, evacuation and } \\
\text { supervising of emergency } \\
\text { and report }\end{array}$ & $x$ & $x$ & $x$ & $x$ & $\begin{array}{l}\mathrm{S} \text { and/or } \\
\text { staff in } \\
\text { OCC } \\
\text { (operation } \\
\text { control } \\
\text { center) }\end{array}$ \\
\hline
\end{tabular}

a function that makes the train automatically pass through a station without stopping in the event of a fire in the station (see Fig. 1).

\section{RESULTS OF METHOD FOR ENSURING SAFETY AND RELIABILITY IN AUTOMATED DRIVING OF TRAINS IN JAPAN}

Automated operation in Japan is implemented through the ATO of an Automated Train Control (ATC) system and is a safe and stable system because ATC ensures high safety and reliability. The idea is that, even if the ATO becomes out of control owing to a breakdown or malfunction, the brake will be safely applied by the ATC and the train will be brought to a stop. The same concept is present in foreign countries as well. Even with the Safety Integrity Level (SIL) stipulated by IEC 62278, the SIL requirement for an ATC is typically 4, (the probability of a dangerous failure per hour is $10^{-9}$ to $10^{-8}$, and in railways that require the highest level of safety integrity, this is referred to as a fail-safe), whereas the SIL requirement for ATO is 2 in many cases (the probability of a dangerous failure per hour of $10^{-7}$ to $10^{-6}$ ). However, in the idea as conceived by Japanese railway operators, both ATO and an ATC use the same computer, and hence both of them are often designed with SIL 4 as their aim, thereby ensuring high safety and reliability. 


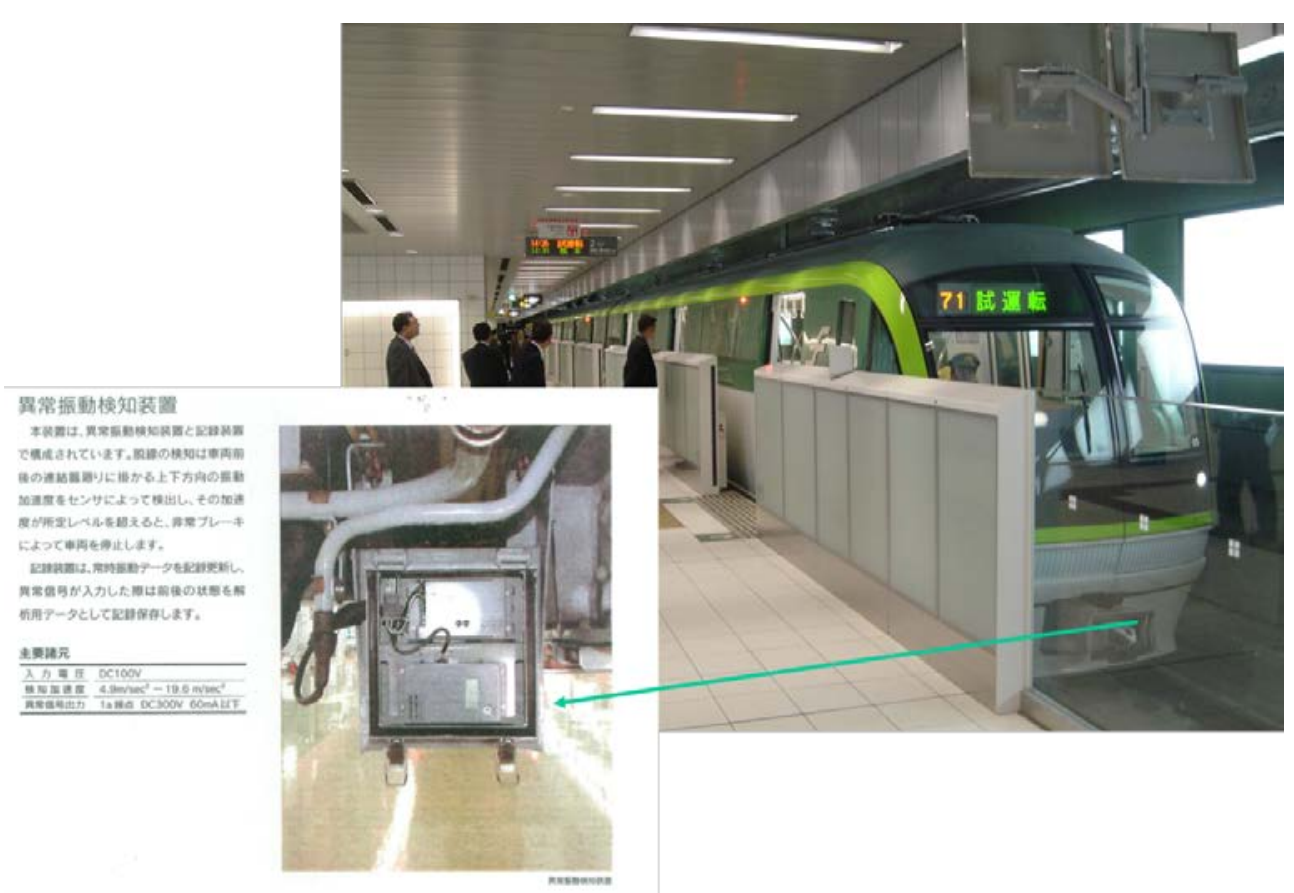

Figure 1: Example of DTO in Japan (Nanakuma Line of Fukuoka City Transportation Bureau equipped with derailment detection device).

Under these circumstances, we put safety analysis into the following system. The method used FMEA (Failure Mode and Effect Analysis) and FTA (Fault Tree Analysis) as our safety policy. At first, through FMEA, the top priority unsafe phenomena were extracted, and FTA was executed against these unsafe phenomena.

Our safety index is to secure the same safety as the present Japanese safety in railways. Therefore, $10-12 / \mathrm{h}$ of unsafe probability is the general criteria in our analysis. To realize these criteria, multi safety corrective actions were accepted and multilayer failure mode were assumed for these FTAs. This is the major difference with other safety analysis in Europe.

\section{EXAMPLE OF SAFETY ANALYSIS FOR AUTOMATED OPERATION (DTO) IN JAPAN}

We next describe a safety analysis for DTO conversion of subway trains that was carried out in the Nanakuma Line of Fukuoka. Our analysis was carried out according to the following process.

First, functions of driver's business details were picked up and these functions were assigned by the system. Therefore, we formulated an alternative table of automated driving tasks, and ascertained the roles of the crew and system in the existing STO and for the case of DTO conversion (see Table 3). We then made a list of probable hazards (dangerous events) and created a corresponding table (manual, STO, DTO, and UTO) for these hazards. The results show that the same degree of safety can be secured with DTO as with the conventional driving of subway trains, and that this is an example that can be put to practical use (see Table 4). Tables 5 and 6 show the on-board equipment and ground equipment installed for DTO 
conversion. The derailment detection device, the function of passing through a station during an emergency situation, and smoke eliminating equipment that makes evacuation easy are some of the design functions that are consciously included in DTO conversion but are not present in the conventional operation of subway trains. This method also conforms to the risk analysis method of IEC 62267, and can be said to be a DTO that adheres to international standards.

Table 3: Example of risk and hazard analysis results for automated operation carried out by Fukuoka City Transportation Bureau (study of division of function).

\begin{tabular}{|c|c|c|c|c|c|c|c|c|}
\hline \multirow[b]{2}{*}{ Business details } & \multirow[b]{2}{*}{ Functions } & \multicolumn{3}{|c|}{ Realization by STO } & \multicolumn{4}{|c|}{ Realization by DTO } \\
\hline & & 离 & 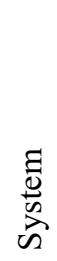 & 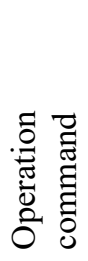 & 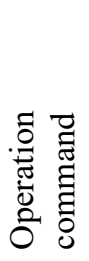 & 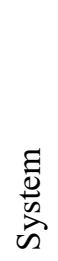 & U & 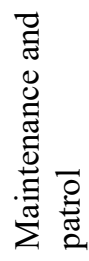 \\
\hline Inspections & $\begin{array}{l}\text { Enter and depart } \\
\text { inspection }\end{array}$ & O & & & & & & O \\
\hline \multirow{7}{*}{$\begin{array}{l}\text { Operation and } \\
\text { driving }\end{array}$} & Shunting & $\mathrm{O}$ & & & & $\mathrm{O}$ & O & \\
\hline & $\begin{array}{l}\text { Open and close of train } \\
\text { doors }\end{array}$ & $\mathrm{O}$ & & & & O & O & \\
\hline & Start control & $\mathrm{O}$ & & & & $\mathrm{O}$ & $\mathrm{O}$ & \\
\hline & $\begin{array}{l}\text { Driving (ACC, DCC } \\
\text { and stopping) }\end{array}$ & $\triangle$ & O & & & O & O & \\
\hline & Train distance & & $\mathrm{O}$ & & & $\mathrm{O}$ & & \\
\hline & Driving arrangement & & & $\mathrm{O}$ & $\mathrm{O}$ & & O & \\
\hline & Route control & & & $\mathrm{O}$ & $\mathrm{O}$ & & $\mathrm{O}$ & \\
\hline \multirow{5}{*}{$\begin{array}{l}\text { Confirmation } \\
\text { and supervising }\end{array}$} & Forward supervising & $\mathrm{O}$ & & & & O & & \\
\hline & $\begin{array}{l}\text { Platform door } \\
\text { supervising }\end{array}$ & $\mathrm{O}$ & & & & O & & \\
\hline & \begin{tabular}{|l|}
$\begin{array}{l}\text { Constant stop } \\
\text { supervising }\end{array}$ \\
\end{tabular} & O & & & & $\mathrm{O}$ & O & \\
\hline & Signal confirmation & $\mathrm{O}$ & & & & $\mathrm{O}$ & & \\
\hline & Equipment supervising & $\mathrm{O}$ & & & & $\mathrm{O}$ & O & \\
\hline \multirow{2}{*}{$\begin{array}{l}\text { Correspondence } \\
\text { to passengers }\end{array}$} & Corresponding & O & & & & O & & O \\
\hline & Information & $\triangle$ & & & & & $\triangle$ & \\
\hline $\begin{array}{l}\text { Communication } \\
\text { and report }\end{array}$ & $\begin{array}{l}\text { Notification of in/out } \\
\text { inspection }\end{array}$ & O & O & & O & & & O \\
\hline
\end{tabular}

Note: Through safety analysis, $\bigcirc$ means the approved the function by system or OCC instead of staff for DTO; $\triangle$ means partially performed. 
Table 4: Examples of ground facilities for automatic driving studied by Fukuoka City Transportation Bureau.

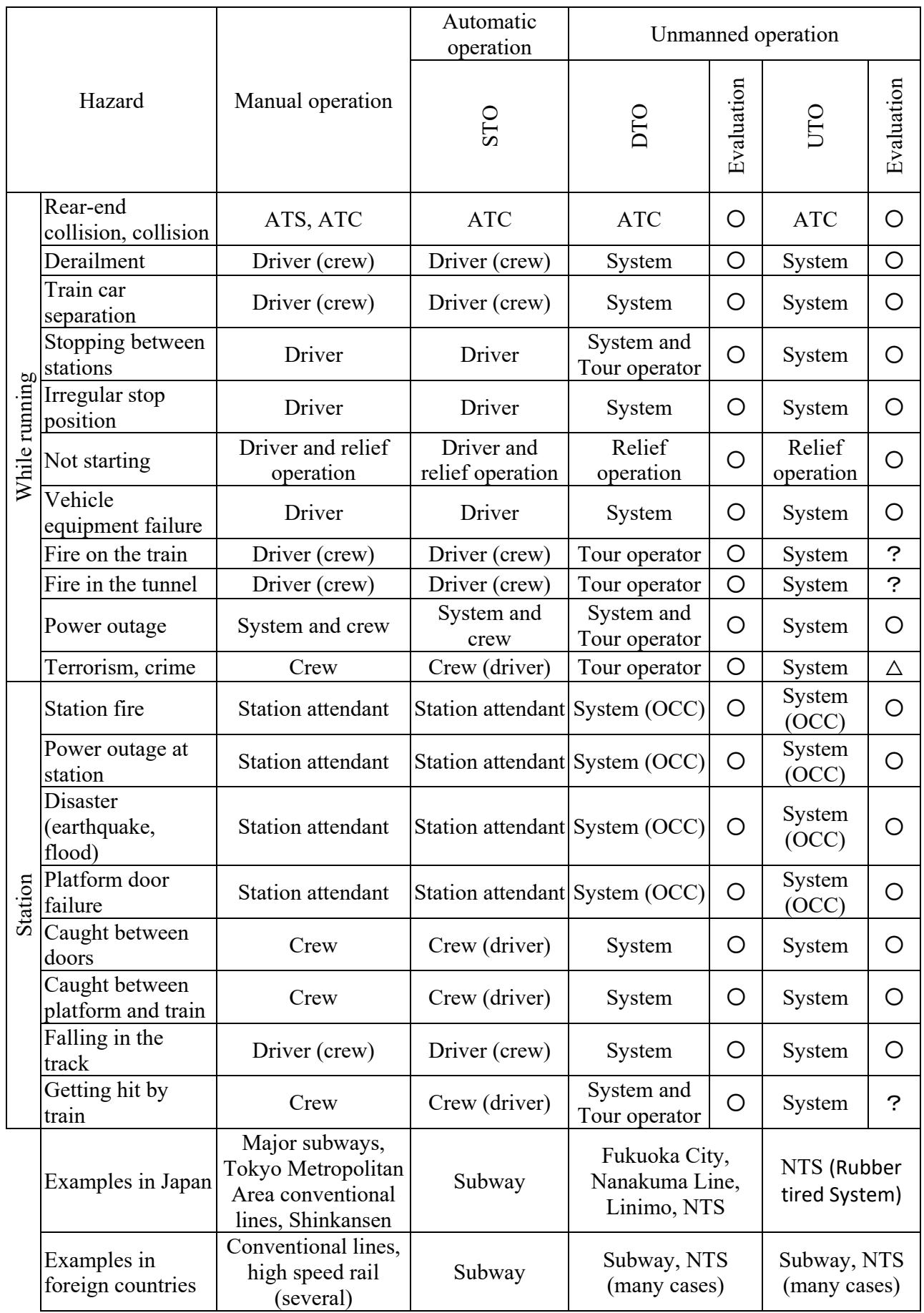


Table 5: On-board equipment at time of DTO introduction.

\begin{tabular}{|c|c|c|c|c|}
\hline Equipment & Apparatus & Functions & STO & DTO \\
\hline \multirow{13}{*}{$\begin{array}{l}\text { Equipment } \\
\text { for driving }\end{array}$} & \multirow{5}{*}{ ATO } & $\begin{array}{l}\text { Back up for location } \\
\text { detection }\end{array}$ & System & System \\
\hline & & \multirow{2}{*}{$\begin{array}{l}\text { Communication of train stop } \\
\text { between stations }\end{array}$} & Driver & System \\
\hline & & & Driver & System \\
\hline & & $\begin{array}{l}\text { re-power running command } \\
\text { from OCC }\end{array}$ & Driver & System \\
\hline & & Inching command & System & System \\
\hline & \multirow[b]{2}{*}{ Brake } & Security brake & System & System \\
\hline & & $\begin{array}{l}\text { EB in case of insufficient } \\
\text { brake }\end{array}$ & $\mathrm{S} /$ Driver & System \\
\hline & \multirow{6}{*}{ Train doors } & $\begin{array}{l}\text { Detection of passengers } \\
\text { caught }\end{array}$ & System & System \\
\hline & & $\begin{array}{l}\text { Automatic door opening and } \\
\text { closing }\end{array}$ & System & System \\
\hline & & \multirow{2}{*}{$\begin{array}{l}\text { After several useless door } \\
\text { opening, report of keeping } \\
\text { door open }\end{array}$} & \multirow[t]{2}{*}{$x$} & System \\
\hline & & & & System \\
\hline & & \multirow{2}{*}{$\begin{array}{l}\text { EB at the time of door } \\
\text { opening during operation }\end{array}$} & \multirow{2}{*}{$x$} & System \\
\hline & & & & System \\
\hline \multirow{7}{*}{$\begin{array}{l}\text { Equipment } \\
\text { for safety }\end{array}$} & \multirow{2}{*}{$\begin{array}{l}\text { Train } \\
\text { communication }\end{array}$} & Alarm signal transmit & System & System \\
\hline & & $\begin{array}{l}\text { EB at reception of alarm } \\
\text { signal }\end{array}$ & System & System \\
\hline & \multirow{3}{*}{$\begin{array}{l}\text { Data } \\
\text { communication }\end{array}$} & \multirow{2}{*}{$\begin{array}{l}\text { Communication between } \\
\text { OCC and signaling system }\end{array}$} & \multirow{2}{*}{$x$} & System \\
\hline & & & & System \\
\hline & & $\begin{array}{l}\text { Dual system and battery } \\
\text { back up }\end{array}$ & $x$ & System \\
\hline & $\begin{array}{l}\text { Obstruction } \\
\text { detection }\end{array}$ & $\begin{array}{l}\text { Report to OCC in case of } \\
\text { detection }\end{array}$ & Driver & System \\
\hline & $\begin{array}{l}\text { Derailment } \\
\text { detection }\end{array}$ & $\begin{array}{l}\text { Brake and report at time of } \\
\text { detection }\end{array}$ & Driver & System \\
\hline \multirow{5}{*}{$\begin{array}{l}\text { Equipment } \\
\text { for } \\
\text { information }\end{array}$} & \multirow{2}{*}{$\begin{array}{l}\text { In-train automatic } \\
\text { announcement }\end{array}$} & $\begin{array}{l}\text { Next stop and arrival } \\
\text { announcement }\end{array}$ & System & System \\
\hline & & $\begin{array}{l}\text { Emergency automatic } \\
\text { announcement }\end{array}$ & Driver & System \\
\hline & \multirow{2}{*}{$\begin{array}{l}\text { In-train guidance } \\
\text { display }\end{array}$} & $\begin{array}{l}\text { Next stop and arrival } \\
\text { information }\end{array}$ & System & System \\
\hline & & $\begin{array}{l}\text { Emergency guidance } \\
\text { information }\end{array}$ & $x$ & System \\
\hline & Lighting & $\begin{array}{l}\text { Emergency lighting over } \\
\text { 30min. }\end{array}$ & System & System \\
\hline
\end{tabular}


Table 6: Ground equipment at time of DTO introduction.

\begin{tabular}{|c|c|c|c|c|}
\hline Equipment & Devices & Functions & STO & UTO \\
\hline \multirow{15}{*}{$\begin{array}{l}\text { Signal related } \\
\text { equipment }\end{array}$} & \multirow{4}{*}{ Operation control } & $\begin{array}{l}\text { Start command, inhibiting } \\
\text { control }\end{array}$ & $\times$ & System \\
\hline & & Supervising of train conditions & Staff & System \\
\hline & & $\begin{array}{l}\text { Abnormal alarm of train stop } \\
\text { position }\end{array}$ & $\times$ & System \\
\hline & & $\begin{array}{l}\text { Train passing in case of station } \\
\text { abnormality }\end{array}$ & Drivers & System \\
\hline & ATO & $\begin{array}{l}\text { Communication with onboard } \\
\text { ATO devices }\end{array}$ & System & System \\
\hline & \multirow{2}{*}{$\begin{array}{l}\text { Limit obstacle } \\
\text { detection }\end{array}$} & Setting with specific sections & System & System \\
\hline & & ATC stop after detection & System & System \\
\hline & \multirow{5}{*}{$\begin{array}{l}\text { Train } \\
\text { communication }\end{array}$} & $\begin{array}{l}\text { Communication between train } \\
\text { and OCC }\end{array}$ & System & System \\
\hline & & \multirow{2}{*}{$\begin{array}{l}\text { Automatic alarm signal } \\
\text { transmits at time of earthquake }\end{array}$} & \multirow{2}{*}{ System } & System \\
\hline & & & & System \\
\hline & & \multirow{2}{*}{$\begin{array}{l}\text { Alarm signal transmit at time of } \\
\text { train stop with doors opening }\end{array}$} & \multirow{2}{*}{$x$} & System \\
\hline & & & & System \\
\hline & \multirow{3}{*}{$\begin{array}{l}\text { Data } \\
\text { communication }\end{array}$} & Redundancy & $\times$ & Dual \\
\hline & & Train stop & $x$ & System \\
\hline & & $\begin{array}{l}\text { Train failure information } \\
\text { reception }\end{array}$ & $x$ & System \\
\hline \multirow{5}{*}{$\begin{array}{l}\text { Safety } \\
\text { equipment }\end{array}$} & \multirow{5}{*}{$\begin{array}{l}\text { Screen platform } \\
\text { doors }\end{array}$} & \multirow{2}{*}{$\begin{array}{l}\text { Obstacle sensors, passenger } \\
\text { caught detection }\end{array}$} & \multirow{2}{*}{ System } & System \\
\hline & & & & System \\
\hline & & $\begin{array}{l}\text { anti-Interlock switch between } \\
\text { train and platform doors }\end{array}$ & $x$ & $\begin{array}{l}\text { System } \\
\text { System }\end{array}$ \\
\hline & & $\begin{array}{l}\text { Interlock between train and } \\
\text { platform doors }\end{array}$ & System & System \\
\hline & & $\begin{array}{l}\text { Supervising of door opening and } \\
\text { closing }\end{array}$ & System & System \\
\hline \multirow{5}{*}{$\begin{array}{l}\text { Disaster } \\
\text { protection and } \\
\text { evacuation }\end{array}$} & Tunnel lighting & $\begin{array}{l}\text { Sufficient illumination during } \\
\text { evacuation }\end{array}$ & System & System \\
\hline & Broadcast & Transmit from OCC to station & System & System \\
\hline & \multirow{2}{*}{ Guidance display } & $\begin{array}{l}\text { Display of abnormal guidance in } \\
\text { station }\end{array}$ & System & System \\
\hline & & $\begin{array}{l}\text { Display of abnormal guidance in } \\
\text { train }\end{array}$ & System & System \\
\hline & Smoke exhaust & $\begin{array}{l}\text { Smoke exhaust with easy } \\
\text { evacuation }\end{array}$ & $\triangle$ & System \\
\hline
\end{tabular}

\section{METHOD OF ENSURING SAFETY WITH AUTOMATED \\ DRIVING TECHNOLOGY OF AUTOMOBILES}

With safety improvement measures aiming at zero accident fatalities, the automated driving technology of automobiles in Japan has been making progress with the advancement of its Information Technology System (ITS) and Advanced Safety Vehicle (ASV) technology. Table 7 shows the levels of automatic driving indicated in the SIP Automatic Driving System 
Research and Development Plan of the Cabinet Office. Currently, the automatic operation system is at the level 2 stage, which is a combination of independent technologies of collision damage mitigation braking, lane-keeping assistance technology, and lane-keeping support control technology. It might be said that this approaches very close to level 3 , in which accelerating, steering, and braking are all performed by the system, and the driver needs to respond only when requested by the system. An example of an automated driving technique, as indicated in the 5th ASV Promotion Plan of the Ministry of Land, Infrastructure, and Transport, is shown for reference.

Fig. 2 shows an example of the evaluation method including security in the automated operation of an urban transportation system. A Reliability, Availability, Maintainability and Safety (RAMS) evaluation and a security evaluation are considered very important and serve as useful references in complying with international standards.

\section{CONCLUSION}

Automated operations (known as DTO and UTO in the international standards) have been implemented in the Japanese railway system, as part of the New Transport System. However, they have not been very highly regarded in conventional trains because of issues including accidents after a platform collapse and at railway crossings, or in ensuring a sense of security during evacuation guidance. However, the rapid progress in automated driving technologies in automobiles, and problems such as labor shortages owing to a declining birthrate and an aging population, have led to studies being conducted on the application of automated driving in the field of conventional railways. In this regard, although utilizing the automated driving technologies in automobiles is important from the viewpoint of cost saving, it goes without saying that ensuring the safety and security of the traditional system is also an essential prerequisite. Therefore, practical application of an automated operation incorporating stateof-the-art technology, while ensuring the safety and reliability of a conventional railway system, is desirable. In this paper security design is described but further study of security problems being undertaken now.

Table 7: The levels of automatic driving indicated in Japan.

\begin{tabular}{|c|c|c|c|}
\hline $\begin{array}{l}\text { Automatic } \\
\text { operation } \\
\text { level }\end{array}$ & Description & \multicolumn{2}{|c|}{$\begin{array}{l}\text { The system that performs } \\
\text { these functions }\end{array}$} \\
\hline Level 1 & $\begin{array}{l}\text { The system performs one of the } \\
\text { operations of acceleration, steering, and } \\
\text { braking }\end{array}$ & \multicolumn{2}{|c|}{ Safe driving support system } \\
\hline Level 2 & $\begin{array}{c}\text { The system performs more than one of } \\
\text { the operations of acceleration, steering, } \\
\text { and braking }\end{array}$ & \multirow{2}{*}{$\begin{array}{l}\text { Semi-automated } \\
\text { driving system }\end{array}$} & \multirow{3}{*}{$\begin{array}{l}\text { Automatic } \\
\text { driving } \\
\text { system }\end{array}$} \\
\hline Level 3 & $\begin{array}{l}\text { The system performs all the operations } \\
\text { of acceleration, steering, and braking } \\
\text { and the driver responds, when } \\
\text { requested by the system }\end{array}$ & & \\
\hline Level 4 & $\begin{array}{l}\text { All the operations of acceleration, } \\
\text { steering, and braking are performed by } \\
\text { an entity other than the driver, and the } \\
\text { driver is not involved at all }\end{array}$ & $\begin{array}{c}\text { Fully automated } \\
\text { driving system }\end{array}$ & \\
\hline
\end{tabular}




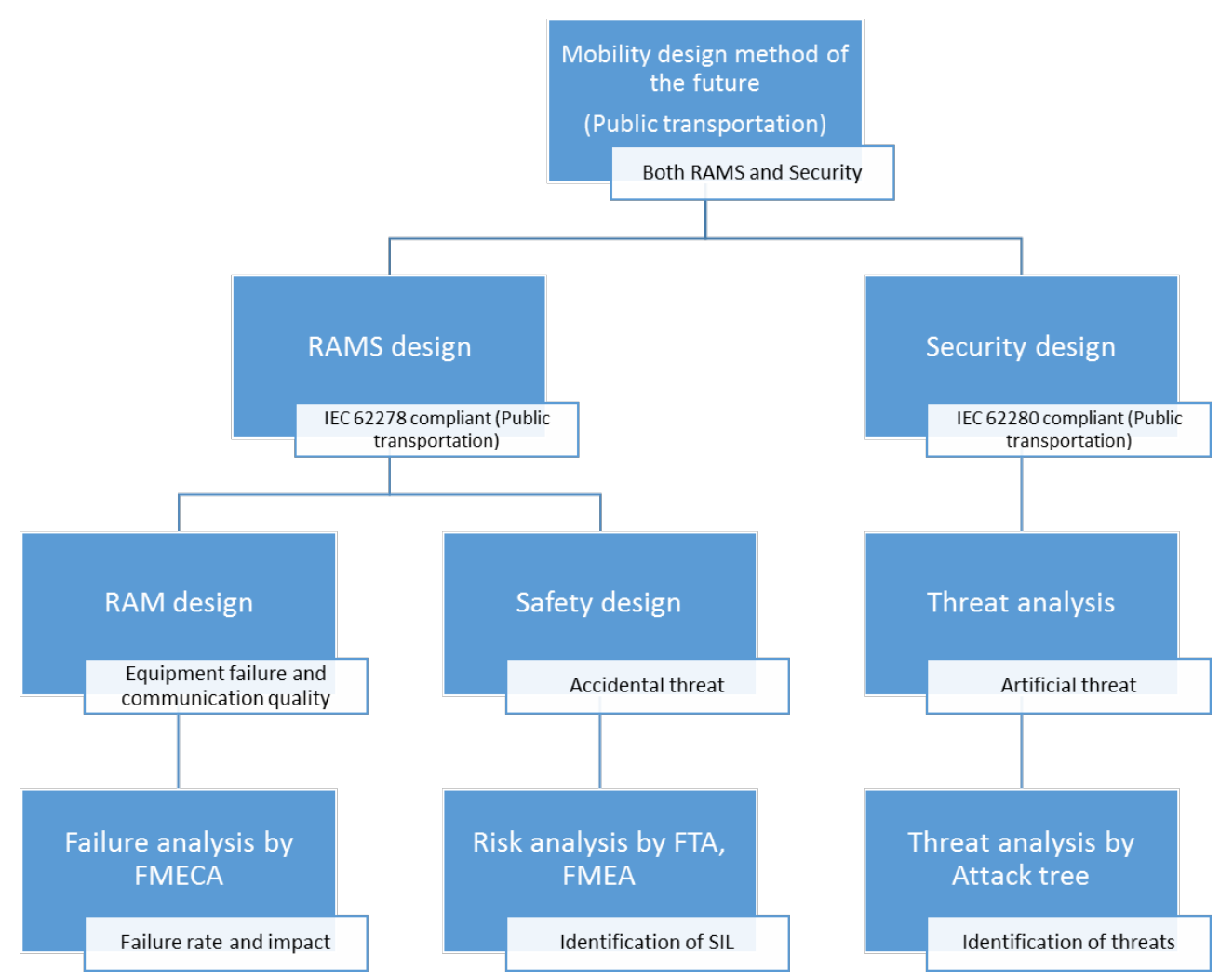

Figure 2: Example of the evaluation method including security in the automated operation of an urban transportation system.

\section{REFERENCES}

[1] Brebbia, C.A., Telles, J.C.F. \& Wrobel, L.C. (eds), Boundary Element Techniques, Springer-Verlag: Berlin and New York, pp. 11-13, 1984.

[2] Osifchin, N. \& Vau, G., Power considerations for the modernization of telecommunications. Proceedings of the Fourth Annual Portable Design Conference, pp. 137-142, 1997.

[3] Test Methods for Evaluating Solid Wastes, Physical/Chemical Methods; U.S. Environmental Protection Agency, Office of Solid Wastes, SW-846, Online. www.epa.gov/epaoswer/hazwastes/test/main.htm. Accessed on: 23 Jun. 2015.

[4] Bratanow, T. \& De Grande, G., Numerical analysis of normal stress in non-Newtonian boundary layer flow. Engineering Analysis, 6(2), pp. 20-25, 1985. 